\title{
PENGARUH EKSTRAK KULIT MANGGIS (GARCINIA MANGOSTANA L.) TERHADAP PERTUMBUHAN BAKTERI VIBRIO CHOLERAE
}

\author{
Ade Selvia Christy
}

Puskesmas Kapongan Situbondo

\begin{abstract}
ABSTRAK
Pengaruh Ekstrak Kulit Manggis (Garcinia Mangostana L.) terhadap Pertumbuhan Bakteri Vibrio cholera. Latar Belakang: Vibrio cholerae merupakan bakteri penyebab penyakit kolera pada manusia. Pada Kabupaten Rejang Lebong Bengkulu penderita diare (termasuk dugaan kolera) mencapai 6460 pada tahun 2009 dan 5747 pada tahun 2010. Pada beberapa daerah endemik dilaporkan telah terjadi resistensi bakteri Vibrio cholerae terhadap antibiotik. Kulit manggis mengandung zat aktif antibakteri yang terdiri dari alkaloid, flavonoid, tannin, dan xanton yang diduga dapat mempengaruhi pertumbuhan bakteri Vibrio cholerae dengan cara mengganggu dinding sel dan membran sitoplasma pada bakteri. Tujuan : Membuktikan ekstrak kulit manggis dapat mempengaruhi pertumbuhan bakteri Vibrio cholerae. Metode Penelitian : True experiment post test only control dengan menggunakan metode dilusi tabung dengan konsentrasi ekstrak kulit manggis 100\%, $50 \%, 25 \%, 12,5 \%, 6,25 \%, 3,125 \%, 1,56 \%, 0,78 \%, 0,39 \%, 0,195 \%, 0,097 \%, 0,048 \%, 0,024 \%, 0,012 \%$, dan $0,006 \%$. Analisis data menggunakan Uji Oneway ANOVA, uji korelasi Pearson, dan uji regresi linier. Hasil : Kadar Hambat Minimum (KHM) dan Kadar Bunuh Minimal (KBM) didapatkan pada konsentrasi 0,78\%. Hasil analisis Oneway ANOVA p=0,000 ( $<<0,05)$ yang menunjukkan adanya perbedaan bermakna pada setiap perlakuan. Hasil analisis korelasi Pearson sebesar -0,809 yang artinya semakin tinggi ekstrak kulit manggis maka semakin menurun jumlah koloni bakteri Vibrio cholerae. Kesimpulan : Ekstrak kulit manggis dapat mempengaruhi pertumbuhan bakteri Vibrio cholerae.
\end{abstract}

\begin{abstract}
Effect of Mangosteen (Garcinia Mangostana L.) Pericarp Extract to the Growth of Vibrio cholerae Bacteria. Background: Vibrio cholerae is the etiologic agent of human cholera. It was noted at Rejang Lebong District, Bengkulu that diarrhea patient rate (including cholera suspect), bit 6460 in 2009 and 5747 in 2010. In several endemic areas, it is reported that antibiotic resistance Vibrio cholera has been developed. Mangosteen pericarp contains antibacterial active substance that consists of alkaloid, flavonoid and xanthone which are considered to be able to interfere growth of Vibrio cholera through interferences in bacterial cell wall and cytoplasmic membrane. Objectives: This study was aimed to prove that mangosteen pericarp extract could affect the growth of Vibrio cholerae. Methods: The design of this study was true experiment post test only control and applied tube dilution method with mangosteen pericarp extract at the concentrations of $100 \%, 50 \%, 25 \%, 12,5 \%, 6,25 \%, 3,125 \%, 1,56 \%, 0,78 \%, 0,39 \%, 0,195 \%, 0,097 \%$, $0,048 \%, 0,024 \%, 0,012 \%$ and 0,006\%. The derived data was further analyzed using oneway ANOVA, Pearson correlation, and linear regression tests. Results : Minimum Inbibitory Concentration (MIC) and Minimum Bactericidal Concentration (MBC) were achieved on $0,78 \%$. Oneway ANOVA analysis resulted with $p=0,000(p<0,05)$ indicated that there were significant difference within each concentrations of mangosteen pericarp extract. Pearson correlation analysis resulted in -0,809 which implied that the higher concentration mangosteen pericarp extract, the lower colony of Vibrio cholerae was found. Conclution: Mangosteen pericarp extract effects the growth of Vibrio cholerae bacteria.
\end{abstract}

Key words : Mangosteen pericarp (Garcinia Mangostana L.), Vibrio cholerae, MIC, MBC

\section{PENDAHULUAN}

Kolera adalah suatu infeksi yang disebabkan oleh bakteri Vibrio cholerae. Orang dapat terinfeksi dengan meminum atau memakan makanan yang terkontaminasi oleh bakteri (Nevondo, 2011). Infeksi terjadi melalui air yang terkontaminasi feses terutama pada orang yang produksi asam lambungnya terganggu. Ciri penyakit ini adalah diare mirip air cucian beras, munculnya mendadak, disertai mual, muntah, sakit perut, dan dehidrasi berat. Bila tidak cepat ditangani akan terjadi kolaps, syok, dan mengakibatkan kematian (Tambayong, 2000). Terdapat banyak antibiotik yang efektif melawan infeksi Vibrio cholerae, diantaranya adalah antibiotik broad spectrum golongan tetrasiklin. Obat tetrasiklin oral cenderung mengurangi pengeluaran feses pada kolera dan memperpendek masa ekskresi Vibrio cholerae. Pada beberapa daerah endemik, dilaporkan telah terjadi resistensi Vibrio cholerae terhadap antibiotik tetrasiklin, dengan dosis pengobatan $500 \mathrm{mg}$. Terjadinya resistensi bakteri 
terhadap antibiotik disebabkan oleh banyak faktor, antara lain adalah kesalahan penggunaan obat, atau terjadi mutasi pada bakteri itu sendiri (Jawetz, 2008).

Salah satu tanaman yang diduga dapat memberi efek antibakteri adalah kulit manggis (Garcinia mangostana L.). Beberapa senyawa utama kandungan kulit buah manggis yang telah terbukti memiliki aktivitas antibakteri adalah golongan xanton. Kulit manggis juga mengandung senyawa yang meliputi mangostin, mangostenol, mangostinon $A$, mangostenon $B$, traperifolixanton, tovofillin $B$, alfa mangostin, beta mangostin, garsinon B, mangostanol, flavonoid, epikatekin. Gartanin, gamma mangostin, garsinon E (Chairungsrilerd et al, 1998; Ho et al, 2002; Suksamsarn et al, 2003; Jung et al, 2006). Penelitian sebelumnya oleh Setiawati (2011) disebutkan bahwa alkaloid, flavonoid, dan tannin dari daun salam dapat mempengaruhi pertumbuhan Vibrio cholerae. Dari hasil uji pendahuluan menggunakan metode dilusi tabung, didapatkan Kadar Hambat Minimal (KHM) ekstrak kulit manggis terhadap bakteri Vibrio cholerae adalah pada konsentrasi $0,78 \%$, konsentrasi ini merupakan konsentrasi terendah yang menunjukkan tidak adanya pertumbuhan bakteri Vibrio cholerae.

Tujuan umum dari penelitian untuk membuktikan pengaruh ekstrak kulit manggis terhadap pertumbuhan bakteri Vibrio cholerae. Sedangkan tujuan khusus dari penelitian ini antara lain untuk mengetahui nilai Kadar Hambat Minimal (KHM) ekstrak kulit manggis terhadap pertumbuhan bakteri Vibrio cholera, untuk mengetahui nilai Kadar Bunuh Minimal (KBM) ekstrak kulit manggis terhadap pertumbuhan bakteri Vibrio cholera, dan untuk membuktikan hubungan antara berbagai konsentrasi ekstrak kulit manggis terhadap pertumbuhan bakteri Vibrio cholera. Manfaat dari penelitian ini dari segi klinis yaitu dapat memberikan informasi bahwa ekstrak kulit manggis secara in vitro memiliki efek sebagai antibakteri terhadap Vibrio cholerae. Dari segi akademik manfaat dari penelitian ini antara lain dapat memberikan informasi ilmiah mengenai pengaruh ekstrak kulit manggis terhadap pertumbuhan bakteri Vibrio cholerae, serta dapat digunakan sebagai penelitian dasar yang dipakai untuk penelitian selanjutnya. Selain itu manfaat pada masyarakat yaitu memberikan informasi kepada masyarakat mengenai manfaat dari kulit manggis sebagai antibakteri

\section{METODE}

\section{Alat dan Bahan}

Alat yang digunakan untuk identifikasi bakteri yaitu ose lurus, ose lengkung, kertas penghisap, minyak emersi, gelas objek, mikroskop, tabung reaksi, dan lampu spirtus. Alat yang digunakan untuk pembuatan ekstrak yaitu kain saring, labu destilasi, vaccum pump, pendingin spiral, water bath, tabung rotavapor, neraca analitik, Erlenmeyer.

Bahan yang digunakan untuk identifikasi bakteri yaitu isolat bakteri Vibrio cholera, pewarna Gram, medium agar TCBS plate, TSI, bahan tes IMViC, urease, motilitas. Bahan yang digunakan untuk pembuatan ekstrak yaitu kulit manggis dan etanol.

\section{Sterilisasi Alat}

Cuci semua peralatan yang dibutuhkan menggunakan sabun hingga bersih dan membiarkan hingga kering. Alat yang bisa disterilisasi dengan autoklaf dibungkus dengan kertas roti dan dimasukkan dalam autoklaf pada suhu $121^{\circ} \mathrm{C}$ dengan tekanan $15 \mathrm{~atm}$, selama 15 menit. Sedangkan alat yang tidak dapat disterilisasi dengan autoklaf bisa disterilkan dengan alkohol 70\%.

\section{Pembuatan Ekstrak Kulit Manggis}

Proses ekstraksi dimulai dari mencuci bersih kulit manggis yang akan digunakan. Potong kulit manggis kecilkecil. Kemudian keringkan kulit manggis dengan oven pada suhu sekitar $40^{\circ} \mathrm{C}$ sampai kering atau dengan metode kering angin. Setelah itu haluskan kulit manggis dengan blender. Pindahkan kulit manggis yang telah dihaluskan ke tempat tertutup kemudian tambahkan pelarut etanol 96\% sampai merendam kulit manggis untuk dilakukan maserasi. Proses maserasi ini dilakukan selama 3 x 24 jam.

Lakukan penyaringan larutan sampai tidak ada cairan yang menetes dari bahan tersebut, jika perlu peras dengan kain saring sehingga semua cairan keluar dari bahan. Pindahkan cairan encer kedalam labu rotavapor kemudian pasang labu pada perangkat rotavapor. Lakukan destilasi pada suhu titik didih pelarut sampai tertinggal cairan pekat pada labu rotavapor lalu tunggu hingga dingin. Hasilnya ditampung pada cawan penguap kemudian di oven selama \pm 2 jam pada suhu $70^{\circ} \mathrm{C}$ untuk menguapkan pelarut yang tersisa sehingga didapatkan hasil ekstrak kulit manggis $100 \%$.

\section{Uji Kepekaan}

Uji kepekaan ekstrak kulit manggis terhadap Vibrio cholerae dilakukan dengan metode dilusi tabung. Kemudian tabung diinkubasi pada suhu $37^{\circ} \mathrm{C}$ selama $18-24$ jam. Kemudian setelah 1 hari tabung dikeluarkan dari inkubator, kemudian dari masing-masing tabung diambil satu ose dan diinokulasikan pada medium agar TCBS dan diinkubasikan lagi 18-24 jam pada suhu $37^{\circ} \mathrm{C}$. Pada hari ketiga Agar TCBS dikeluarkan dari inkubator, kemudian dilakukan pengamatan kuantitatif pada masing-masing konsentrasi dengan cara menghitung jumlah koloni bakteri dengan colony counter sehingga didapatkan KBM.

\section{Analisa Data}

Data yang diperoleh yaitu data konsentrasi ekstrak kulit manggis dan data jumlah koloni bakteri. Analisis yang digunakan adalah uji Oneway ANOVA, uji korelasi Pearson, dan uji regresi linier.

\section{HASIL DAN PEMBAHASAN}

Penentuan pertumbuhan bakteri Vibrio cholerae secara kualitatif berdasarkan tingkat kekeruhan dengan hasil pengamatan pada uji dilusi tabung pada hari kedua setelah diinkubasi selama $18-24$ jam pada suhu $37{ }^{\circ} \mathrm{C}$ dapat dilihat pada tabel 1. Berdasarkan tingkat kekeruhan pada tabel 1 dari dua kali pengulangan terhadap masing-masing konsentasi didapatkan hasil pada konsentrasi $0,78 \%$ mulai terlihat jernih sehingga didapatkan KHM pada konsentrasi $0,78 \%$. Hasil penghitungan pertumbuhan bakteri Vibrio 
cholerae pada medium agar TCBS dengan berbagai konsentrasi ekstrak kulit manggis dapat dilihat pada tabel 2. Dapat dilihat bahwa pada konsentrasi $0,78 \%$ mulai tampak terjadinya penurunan pada pertumbuhan bakteri Vibrio cholerae.

Hasil analisis Oneway ANOVA untuk jumlah koloni rata-rata Vibrio cholerae per cawan didapatkan nilai $\mathrm{p}=0,000$ $(\mathrm{p}<0,05)$. Hasil ini mengandung pengertian bahwa terdapat perbedaan yang bermakna pada beberapa konsentrasi ekstrak kulit manggis terhadap jumlah koloni rata-rata Vibrio cholerae. Pada analisis korelasi Pearson didapatkan hasil dengan nilai $-0,809$ dengan $\mathrm{p}=0,000(\mathrm{p}<0,01)$. Hasil ini menunjukkan adanya hubungan yang bermakna negatif yang artinya dengan semakin tinggi konsentrasi ekstrak kulit manggis akan semakin menurun jumlah koloni rata-rata Vibrio cholerae per cawan. Pada analisis regresi linier didapatkan nilai koefisien determinasi $\left(\mathrm{R}\right.$ Square $=\mathrm{R}^{2}$ ) adalah sebesar $65,5 \%$, yang artinya bahwa sebesar $65,5 \%$ jumlah koloni rata-rata Vibrio cholerae per cawan dipengaruhi oleh ekstrak kulit manggis. Sedangkan sisanya sebesar $34,5 \%$ dipengaruhi oleh faktor lain yang tidak dibahas dalam penelitian ini, seperti kandungan senyawa antimikroba, $\mathrm{pH}$, atau materi organik.

Faktor lain yang kemungkinan mempengaruhi penelitian ini yaitu tidak diketahui usia dari kulit manggis yang digunakan menyebabkan tidak diketahuinya kandungan polifenol dalam kulit manggis, sedangkan kandungan polifenol terbaik dalam kulit manggis didapatkan pada manggis yang dipanen 4 bulan setelah anthesis (bunga mekar) (Hadriyono, 2011). Kemungkinan pengaruh $\mathrm{pH}$ sebagai faktor yang berpengaruh pada penelitian ini adalah $\mathrm{pH}$ dari ekstrak karena ekstrak kulit manggis yang digunakan memiliki $\mathrm{pH}$ yang rendah yaitu 3,7 sedangkan bakteri Vibrio cholerae merupakan bakteri yang tidak tahan terhadap asam sehingga dengan kadar keasaman yang tinggi tersebut dapat menghambat dan membunuh bakteri Vibrio cholerae. Kemungkinan pengaruh materi organik pada penelitian ini adalah karena bakteri dapat melakukan penguraian materi organik secara anaerob yang dapat menghasilkan asam sehingga dapat meningkatan kadar keasaman di sekitar bakteri dan dapat menghambat serta membunuh bakteri Vibrio cholerae.
Tabel 1. Tingkat kekeruhan yang dihasilkan pada media Nutrient broth oleh bakteri Vibrio cholerae dalam beberapa konsentrasi ekstrak kulit manggis

\begin{tabular}{ccc}
\hline Konsentrasi & \multicolumn{2}{c}{ Tingkat Kekeruhan } \\
$(\%)$ & Ulangan 1 & Ulangan 2 \\
100 & Keruh & Keruh \\
50 & Keruh & Keruh \\
25 & Keruh & keruh \\
12,5 & Keruh & Keruh \\
6,25 & Keruh & Keruh \\
3,125 & Keruh & Keruh \\
1,56 & Keruh & Keruh \\
0,78 & Keruh & Keruh \\
0,39 & agak keruh & agak keruh \\
0,195 & agak keruh & agak keruh \\
0,097 & agak keruh & agak keruh \\
0,048 & agak keruh & agak keruh \\
0,024 & Keruh & Keruh \\
0,012 & keruh & Keruh \\
0,006 & Keruh & Keruh \\
0 & Keruh & Keruh \\
\hline
\end{tabular}

Tabel 2. Jumlah koloni rata-rata Vibrio cholerae per cawan dalam beberapa konsentrasi ekstrak kulit manggis

\begin{tabular}{|c|c|c|c|}
\hline \multirow{2}{*}{$\begin{array}{c}\text { Konsentrasi } \\
(\%)\end{array}$} & \multicolumn{2}{|c|}{$\begin{array}{c}\text { Jumlah Bakteri } \\
\text { Koloni }\end{array}$} & \multirow{2}{*}{$\begin{array}{c}\text { Rata- } \\
\text { rata } \\
\text { jumlah } \\
\text { bakteri } \\
\text { (koloni }\end{array}$} \\
\hline & $\begin{array}{c}\text { Ulangan } \\
\quad 1\end{array}$ & $\begin{array}{c}\text { Ulangan } \\
2\end{array}$ & \\
\hline 0 & 1103 & 3996 & $\begin{aligned} & 2549.5 \\
& \approx 2550\end{aligned}$ \\
\hline 0.006 & 1998 & 2092 & 2045 \\
\hline 0.012 & 2738 & 2025 & $\begin{array}{l}2381.5 \\
\approx 2382 \\
\end{array}$ \\
\hline 0.024 & 1086 & 1216 & 1151 \\
\hline 0.048 & 1200 & 1084 & 1142 \\
\hline 0.097 & 686 & 815 & $\begin{array}{c}750.5 \approx \\
751\end{array}$ \\
\hline 0.195 & 474 & 520 & 497 \\
\hline 0.39 & 136 & 409 & $\begin{array}{r}272.5 \approx \\
273\end{array}$ \\
\hline 0.78 & 44 & 0 & 22 \\
\hline 1.56 & 0 & 0 & 0 \\
\hline 3.125 & 0 & 0 & 0 \\
\hline 6.25 & 0 & 0 & 0 \\
\hline 12.5 & 0 & 0 & 0 \\
\hline 25 & 0 & 0 & 0 \\
\hline 50 & 0 & 0 & 0 \\
\hline 100 & 0 & 0 & 0 \\
\hline
\end{tabular}


Dari hasil penelitian diatas membuktikan bahwa ekstrak kulit manggis dapat menghambat dan membunuh bakteri Vibrio cholerae. Hal ini diduga karena kandungan zat pada kulit manggis memiliki potensi sebagai antibakteri, yaitu alkaloid, flavonoid, tannin, dan xanton. Alkaloid sebagai antibakteri bekerja dengan mengganggu komponen penyusun peptidoglikan. Peptidoglikan ini merupakan salah satu lapisan penyusun dinding sel bakteri dan bakteri Gram negatif memiliki lapisan peptidoglikan yang tipis sehingga jika terjadi gangguan pada komponen penyusun peptidoglikan maka lapisan dinding sel tidak akan terbentuk secara utuh dan dapat mengakibatkan kematian sel (Cowan, 1999; Dzen, 2003).

Flavonoid memiliki efek antibakteri dengan mempengaruhi dinding sel dan membran sel bakteri. Flavonoid membentuk kompleks dengan protein ekstraseluler sehingga dapat mengganggu integritas membran sel bakteri. Selain itu, senyawa ini juga terlarut dengan dinding sel yang dapat menyebabkan kerusakan dinding sel bakteri. Flavonoid juga bersifat lipofilik yang dapat menghancurkan membran sel sehingga dapat membunuh bakteri (Cowan, 1999; Dzen, 2003; Robinson, 1991).

Tannin sebagai senyawa antibakteri mempengaruhi dinding sel dan membran sel karena diduga dapat mengkerutkan dinding dan membran sel bakteri yang dapat menyebabkan gangguan permeabilitas dan gangguan aktivitas hidup bakteri sehingga pertumbuhan bakteri terhambat dan menyebabkan kematian bakteri (Ajizah, 2004). Selain itu, tannin membentuk kompleks dengan polisakarida dinding sel (Cowan, 1999).

Xanton sebagai suatu senyawa polifenol dapat merusak membran sel mikroorganisme. Kerusakan membran menyebabkan bakteri kehilangan metabolisme penting dari sel bakteri sehingga dapat menyebabkan kematian bakteri (Soraya, 2007).

Penelitian terdahulu telah disebutkan bahwa kulit manggis memiliki efektivitas sebagai antibakteri. Penelitian oleh Suksamrarn (2003) membuktikan bahwa kandungan xanton dari manggis memperlihatkan aktivitas sebagai antibakteri terhadap bakteri Mycobacterium tuberculosis. Kandungan $\beta$-mangostin, $\beta$-mangostin, dan garcinone $D$ menunjukkan aktivitas antibakteri yang paling poten dengan nilai MIC sebesar $6,25 \mathrm{mcg} / \mathrm{ml}$ dan $\beta$-mangostin menunjukkan aktivitas penghambatan yang lebih rendah dengan nilai MIC sebesar $25 \mathrm{mcg} / \mathrm{ml}$ sedangkan turunan xanton yang lain juga menunjukkan aktivitas penghambatan terhadap bakteri Mycobacterium tuberculosis yang lebih rendah yaitu dengan nilai MIC $12,5 \mathrm{mcg} / \mathrm{ml}, 100 \mathrm{mcg} / \mathrm{ml}$, dan $200 \mathrm{mcg} / \mathrm{ml}$. Penelitian oleh Sakagami (2005) juga membuktikan bahwa xanton dari manggis memiliki aktivitas antibakteri terhadap Enterococci dan Staphylococcus aureus. Kandungan Kandungan á-mangostin menunjukkan aktivitas antibakteri terhadap Enterococci dengan MIC antara 3,13 - 6,25 $\mathrm{mcg} / \mathrm{ml}$ sedangkan â-mangostin menunjukkan aktivitas antibakteri dengan MIC sebesar $25 \mathrm{mcg} / \mathrm{ml}$. Pada penelitian menggunakan Staphylococcus aureus, á-mangostin menunjukkan aktivitas antibakteri dengan MIC sebesar 6,26-12,5 mcg/ml sedangkan â-mangostin menunjukkan aktivitas antibakteri dengan MIC $>100 \mathrm{mcg} /$ ml. Pada penelitian ekstrak kulit manggis terhadap pertumbuhan bakteri Vibrio cholerae ini didapatkan Kadar
Hambat Minimal (KHM) dan Kadar Bunuh Minimal (KBM) pada konsentrasi $0,78 \%$.

Penelitian sebelumnya Suksamrarn (2003) menguji efek antibakteri manggis menggunakan bakteri Mycobacterium tuberculosis. Mycobacterium tuberculosis merupakan bakteri tahan asam. Pada pengamatan dengan mikroskop elektron, tampak dinding sel dan membran plasmanya terdiri atas tiga lapisan. Susunan dinding sel bakteri ini sangat kompleks dan berbeda dengan bakteri Gram positif dan Gram negatif. Dinding sel tersebut tersusun dari bahan seperti lilin (wax) serta dibawah lapisan lilin tersebut terdapat membran sitoplasma yang bersifat semipermeabel sehingga senyawa antibakteri tidak mudah masuk ke dalam sel. (Dzen, 2003). Pada ekstrak kulit manggis ini terdapat kandungan

xanton sebagai senyawa antibakteri yang dapat mempengaruhi pertumbuhan bakteri Mycobacterium tuberculosis. Selain itu juga terdapat senyawa antibakteri lain yaitu flavonoid, alkaloid, dan tannin yang diduga juga dapat memberikan efek antibakteri. Senyawa antibakteri yang terdapat pada ekstrak kulit manggis ini dapat mempengaruhi dinding dan membran sel bakteri yang dapat menyebabkan denaturasi protein karena sifatnya sebagai senyawa fenol, tetapi kemungkinan membutuhkan konsentrasi yang lebih tinggi ataupun waktu yang lebih lama dalam memberikan efek antibakteri terhadap Mycobacterium tuberculosis karena lapisan penyusun dinding dan membran sel yang lebih kompleks sehingga sulit untuk ditembus oleh senyawa antibakteri.

Bakteri Mycobacterium tuberculosis yang tahan terhadap asam dapat mati dengan ekstrak kulit manggis ini sehingga bakteri Vibrio cholerae yang tidak tahan terhadap asam kemungkinan juga dapat mati karena pengaruh ekstrak kulit manggis ini. Namun, belum dapat diketahui secara pasti mengenai mekanisme kematian bakteri dikarenakan pengaruh zat aktif dalam kulit manggis atau dikarenakan keasaman dari ekstrak kulit manggis yang digunakan. Selain itu, bakteri Gram negatif seperti Vibrio cholerae ini juga memiliki susunan dinding sel yang lebih sederhana sehingga kemungkinan lebih mudah ditembus oleh senyawa antibakteri dan pada konsentrasi kecil sudah dapat memberikan efek antibakteri.

Penelitian sebelumnya, Sakagami (2005) melakukan uji anti bakteri manggis terhadap bakteri Enterococci dan Staphylococcus aureus. Bakteri Enterococci dan Staphylococcus aureus merupakan bakteri Gram positif. Bakteri Gram positif memiliki struktur dinding sel yang terdiri dari peptidoglikan dengan lapisan yang lebih banyak atau lebih tebal di bandingkan dengan lapisan peptidoglikan pada bakteri Gram negatif. Jika bakteri Gram negatif mengalami gangguan pada lapisan penyusun peptidoglikan maka lapisan dinding sel tidak dapat terbentuk secara utuh dan dapat mengakibatkan kematian bakteri (Cowan, 1999; Dzen, 2003). Ekstrak kulit manggis ini memiliki kandungan xanton, flavonoid, alkaloid, dan tannin yang dapat mengganggu pembentukan dinding sel dan dapat menyebabkan kematian bakteri. Oleh karena bakteri Gram negatif seperti Vibrio cholerae ini memiliki lapisan penyusun dinding sel yang lebih tipis dibandingkan dengan bakteri Gram positif sehingga kemungkinan dapat memberikan efek antibakteri pada konsentrasi yang lebih kecil. 
Keterbatasan dalam penelitian ini yaitu masih menggunakan ekstrak kasar kulit manggis dimana masih banyak bahan aktif yang terkandung dalam ekstrak kulit manggis sehingga belum diketahui secara pasti bahan aktif lain yang juga mempunyai daya antibakteri terhadap bakteri Vibrio cholerae. Selain itu, usia kulit manggis yang digunakan. Kulit manggis yang mempunyai kandungan polifenol terbaik adalah manggis yang dipanen 4 bulan setelah anthesis (bunga mekar (Hadriyono, 2011). Dalam penelitian ini tidak diketahui usia manggis yang digunakan. Oleh karena itu, untuk penelitian selanjutnya disarankan untuk menggunakan kulit manggis yang diambil dari perkebunan manggis sehingga dapat diketahui secara pasti usia manggis yang digunakan agar dapat diperoleh kandungan polifenol terbaik. Selain itu, keterebatasan lain dalam penelitian ini adalah belum diketahui secara pasti mengenai mekanisme pasti kematian bakteri Vibrio cholerae ini dikarenakan mekanisme kerja senyawa aktif antibakteri dalam kulit manggis atau karena kadar keasaman yang tinggi dalam ekstrak kulit manggis sehingga diperlukan penelitian lebih lanjut untuk mengetahui secara pasti mengenai mekanisme kematian bakteri Vibrio cholerae menggunakan ekstrak kulit manggis ini.

\section{SIMPULAN}

Berdasarkan hasil dan pembahasan dalam penelitian ini, maka dapat ditarik kesimpulan bahwa ekstrak kulit manggis dapat mempengaruhi pertumbuhan bakteri Vibrio cholera, nilai KHM dan KBM ekstrak kulit manggis terhadap pertumbuhan bakteri Vibrio cholerae adalah pada konsentrasi $0,78 \%$

\section{DAFTAR PUSTAKA}

Ajizah A, 2004, Sensitivitas Salmonella Typhimurium Terhadap Ekstrak Daun Psidium Guajava, Jurnal Bioscientiae Volume 1 No. $1: 31-8$ Program Studi Pendidikan Biologi FKIP Universitas Lambung Mangkurat.

Amelia Sri, 2005, Vibrio cholerae, Diakses 19 Agustus 2011, <http://Repository. Usu. Ac.Id/Bitstream/ 123456789/3576/1/05010682.Pdf>.

Bishop Nita, 2003, The Hierarchy of Flavonoid Antioxidan Potentials, American Assosiation of Neurophatic Physicians Convention, Portland.

BPS Kabupaten Rejang Lebong, 2011, Kabupaten Rejang Lebong Dalam Angka 2011, Percetakan Merdeka Curup, Bengkulu, pp. 46, 178.

Chairungsrilerd N, Furukawa KI, Ohta T, Nozoe S, Ohizumi Y., 1998, Gamma-Mangostin, A Novel Type Of 5-Hydroxytryptamine 2A Receptor Antagonist, Naunyn Schmiedebergs Arch Pharmacol., 357(1):2531.

Chambers Henry F, 2008, Senyawa Antimikroba Inhibitor Sintesis Protein dan Berbagai Senyawa Antibakteri, In: Dasar Farmakologi Terapi, Edisi 10, ECG, Jakarta, pp. 1214-1245.

Chomnawang MT, Surassmo S, Wongsariya K, et al, 2008, Antibacterial Activity Of Thai Medicinal Plants Against Methicillin- Resistant Staphylococcus Aureus, Volume
80, di akses 25 Desember 2012, <http:// www.ncbi.nlm.nih.gov/pubmed/19022354 >.

Cowan Marjorie M, 1999, Plant Products as Antmicrobial Agents :Clinical Microbiology Review, Ohoi : American Society for Microbiology, pp. 565 - 573.

Dahlan Sopiyudin, 2009, Statistik Untuk Kedokteran dan Kesehatan, Salemba Medika, Jakarta

Dwidjoseputro D, 1994, Dasar-Dasar Mikrobiologi, Djambatan, Jakarta, pp. 38, 134.

Dzen S.M, Roekistiningsih, Santoso S, et al, 2003, Bakteriologi Medik, Tim Mikrobiologi Fakultas Kedokteran Universitas Brawijaya, Bayumedia Publising, Malang.

Faruque SM, Nair G, 2008, Vibrio cholerae, di akses 12 September 2011, <http://en.wikipedia.org/wiki/ Vibrio_cholerae>.

Feigin D. Ralph, 2004, Textbook of Pediatric Infectious Disease Volume 1, Fifth edition, Saunders, USA.

Hadi Sutrisno, 1981, Metodologi Research, Jilid 3, Yayasan Penerbit Fakultas Psikologi UGM, Yogyakarta.

Hadriyono Kukuh, 2011, 'Karakter Kulit Manggis, Kadar Polifenol Dan Potensi Antioksidan Kulit Manggis (Garcinia Mangostana L.) Pada Berbagai Umur Buah Dan Setelah Buah Dipanen' Departemen Agronomi dan Holtikultura Fakultas Pertanian Institut Pertanian Bogor, Bogor.

Hart T. \& Shears P, 1997, Atlas Berwarna Mikrobiologi Kedokteran, Hipokrates, Jakarta.

Hasyim A, Iswari K, 2008, Manggis Kaya Antioksidan, di akses 16 Februari 2011 <http:// www.webhorti.puslithorti-itbang.info/IPTEK/ Hasyim_ manggis.pdf $>$

Ho CK, Huang YL, Chen CC, 2002, Garcinone E, A Xanthone Derivative, Has Potent Cytotoxic Effect Against Hepatocellular Carcinoma Cell Lines, Planta Med., 68(11):975-979.

Huang, Y.L, Chen, C.C, Chen, Y.J, et al., 2001, Three Xanthones And A Benzophenone From Garcinia Mangostana, J. Nat. Prod. 64, pp. 903-906.

ICUC, 2003, Fruit to the Future Mangosteen, Factsheet, No 8, International Centre for Underutilized Crops.

Jawetz, Melnick, Adelberg, 2008, Mikrobiologi Kedokteran, Edisi 23, ECG, Jakarta.

Ji X, Avula B, Khan I.A, 2007, Quantitative And Qualitative Determination Of Six Xanthones In Garcinia Mangostana L. By LC-PDA And LC-ESI-MS, J. Pharm Biomed Anal, 43, pp. 1270-1276.

Jung HA, Su BN, Keller WJ, et al, 2006, Antioxidant Xanthones From The Pericarp Of Garcinia Mangostana (Mangosteen), J Agric Food Chem., 54(6):2077-2082.

Kandun Nyoman, 2008, Depkes Terjunkan Tim Penanggulangan KLB Kolera di Papua, di akses 12 Maret 2012, <http://lipsus.kompas.com/ grammyawards/read/2008/08/09/15125483/ Depkes.Terjunkan. Tim.Penanggulangan. KLB. Kolera.di.Papua.>.

Lenny Sovia, 2006, Senyawa Flavonoida, Fenilpropanoida, dan Alkaloida, di akses 9 April 2012, <http:// biologyeast borneo. com/wp-content/uploads/2011/ 09/Senyawa-flavon-dan-alkaloid.pdf $>$ 
Lesmana Murad, 2004, Perkembangan Mutakhir Infeksi Kolera, Volume 23, Universitas Trisakti, Jakarta, pp. 101-109.

Levinson Warren, 2006, Medical Microbiology and Immunology, Ninth edition, The McGraw-Hill Companies, Inc., USA.

Marlina, Almasdy Dedy, Aufa Insanil, 2007, Deteksi Gen ctx Pada Bakteri Vibrio cholerae pada Isolat Limbah Cair Rumah Sakit dan Uji Resistensinya Terhadap Beberapa Antibiotik, FMIPA Universitas Andalas Padang, diakses tanggal 2 Agustus 2012, <http://digilib.unsri.ac.id/ download/jstf_v12_2_07_marlina090814.pdf>

Masduki I, 1996, Efek Antibakteri Ekstrak Biji Pinang (Areca catechu) Terhadap S. aureus dan E. coli, Cermin Dunia Kedokteran 109 : 21-4.

Muhlisah F, 2008, Tanaman Obat Keluarga (TOGA), Penebar Swadaya, Jakarta.

Nevondo Ts, Cloete Te, 2011, The Global Cholera Pandemic, Diakses 12 Maret 2012, <http:// www.scienceinafrica.co.za/2001/September/ Cholera.htm>.

Obolskiy D, Pischel I, Siriwatanametanon N, et al, 2009, Garcinia Mangostana L.: A Phytochemical And Pharmacological Review. Phytother. Res., 23: 1047-1065.

Pansera M.R, 2004. Extraction Of Tannin By Acacia Mearnshin With Supercrutical Fluid. Brazilian Archip.

Prihatman K, 2000, Manggis (Garcinia Mangostana L.), Kantor Deputi Menegristek Bidang Pendayagunaan dan Pemasyarakatan Ilmu Pengetahuan dan Teknologi BPP Teknologi, Jakarta.

Robinson T, 1991, Kandungan Organik Tumbuhan Tingkat Tinggi in : Juliantina Farida, Manfaat Sirih Merah (Piper crocatum) sebagai Agen Antibakterial terhadap Bakteri Gram Positif dan Bakteri Gram Negatif, Jurnal Kesehatan dan Kedokteran Indonesia, diakses 2 Agustus 2012, <http://journal.uii.ac.id/index.php/ JKKI/article/viewFile/543/467>

Ropiah Siti, 2009, 'Perkembangan Morfologi dan Fisiologi Buah Manggis (Garcinia Mangostana L.) Selama Pertumbuhan dan Pematangan', Sekolah Pascasarjana Institut Pertanian Bogor, Bogor.

Sakagami Y, Iinuma M, Piyasena KG, et al, 2005, Antibacterial Activity Of Alpha-Mangostin Against Vancomycin Resistant Enterococci (VRE) And Synergism With Antibiotics, Phytomedicine, 12(3):203-208.

Saleh M, Mawardi, Eddy, et al, 2007, Determinasi Dan Morfologi Buah Eksotis Potensial di Lahan Rawa, di akses 12 Agustus 2011, <http://balittra.l itbang. deptan.go.id/eksotik/Monograf - 7.pdf >.

Saleh M, Mawardi, Khairullah, 2007, Potensi Buah Unggulan Lahan Rawa Manggis, Durian Dan Srikaya, di akses 12 Agustus 2011, <http://balittra.litbang.deptan.go.id/ eksotik/Monograf - 6.pdf >.

Setiawati Umi, 2011, Pengaruh Ekstrak Daun Salam (Syzygium polyanthum Wight Walp) Terhadap Pertumbuhan Vibrio cholerae, Skripsi Universitas Muhammadiyah, Malang

Soemarsono, 2007, Kolera, In: Buku Ajar Ilmu Penyakit Dalam Jilid 3, Edisi 4, FKUI, Jakarta, pp. 1727-1731.

Soraya N, 2007, Sehat dan Cantik Berkat Teh Hijau, Penebar Plus+, Jakarta, pp. 51-52.
Sudarsono, Gunawan D, Purnomo, et al, 2002, Tumbuhan Obat II : Hasil Penelitian, Sifat-sifat, Penggunaan, Pusat Studi Obat Tradisional Universitas Gadjah Mada, Yogyakarta.

Suksamrarn S, Suwannapoch N, Phakhodee W, et al, 2003, Antimycobacterial Activity Of Prenylated Xanthones From The Fruits Of Garcinia Mangostana, Chem Pharm Bull (Tokyo)., 51(7):857-859.

Supranto J, 2007, Teknik Sampling Survey \& Eksperimen, PT Rineka Cipta, Jakarta.

Tambayong J, 2000, Mikrobiologi Untuk Keperawatan, Widya Medika, Jakarta.

Waturangi E, Lay W, Soka, 2007, Minuman Jajanan Anak Sekolah Terkontaminasi Bakteri Patogen, di akses 12 Maret 2012, <http://cybermed.cbn.net.id/cbprtl/ cybermed/detail.aspx? $\mathrm{x}=$ healthnews $\& \mathrm{y}=$ cybermed $|0| 0|5| 4646>$.

Walker E.B, 2007, HPLC Analysis Of Selected Xanthones In Mangosteen Fruit, J. Sep, Sci. 30, 1229-1234. 